\title{
Activity and Stability of Immobilized Lipase for Utilization in Transesterification of Waste Cooking Oil
}

\author{
Azianna Gusniah, Harumi Veny, Fazlena Hamzah* \\ Faculty of Chemical Engineering, Universiti Teknologi MARA (UiTM), 40450 Shah Alam, \\ Selangor, Malaysia.
}

Received: $5^{\text {th }}$ December 2019; Revised: $28^{\text {th }}$ January 2020; Accepted: $29^{\text {th }}$ January 2020; Available online: 28th February 2020; Published regularly: April 2020

\begin{abstract}
Biodiesel is fatty acid methyl ester that commonly derived from vegetable oils and animal fats that can be produced through enzymatic transesterification using lipase. In this study, three different types of lipase were used, which are Lipase Immobilized Pseudomonas cepacia, PcL, Thermomyces lanuginosus, TLIM, and Candida Antarctica A (recombinant from Aspergillus oryzae), CALA. These lipases were compared based on their activity at different $\mathrm{pH}(6-10)$, temperature $\left(30-50{ }^{\circ} \mathrm{C}\right)$, activation energy, and amount of lipase loading for hydrolysis of $\mathrm{p}$-NPA into $\mathrm{n}$-NP. The result indicates that among the lipase used in the study, CALA is the preferable biocatalyst in the hydrolysis of $p$-NPA due to the minimum energy required and higher enzymatic activity at $20 \mathrm{mg}$ of enzyme loading. PcL and CALA used in the study gave the optimum activity at $\mathrm{pH} 9$ except for TLIM at $\mathrm{pH} 8$ and the optimum temperature at 40 ${ }^{\circ} \mathrm{C}$. The kinetic data obtained for CALA in this reaction were $K_{m}=57.412 \mathrm{mM}$ and $V_{m}=70 \mu \mathrm{M} / \mathrm{min}$. This finding shows that CALA is beneficial biocatalysts for the transesterification process to obtain a higher product with lower activation energy. Copyright $@ 2020$ BCREC Group. All rights reserved
\end{abstract}

Keywords: Enzyme Activity; Immobilized Lipase; Transesterification; Waste Cooking Oil

How to Cite: Gusniah, A., Veny, H., Hamzah, F. (2020). Activity and Stability of Immobilized Lipase for Utilization in Transesterification of Waste Cooking Oil. Bulletin of Chemical Reaction Engineering \& Catalysis, 15(1), 242-252 (doi:10.9767/bcrec.15.1.6648.242-252)

Permalink/DOI: https://doi.org/10.9767/bcrec.15.1.6648.242-252

\section{Introduction}

Biodiesel is a mixture of alkyl ester, which is produced through the catalytic or non-catalytic process of triglycerides where it can be any vegetable oil or animal fats with short-chain [1,2]. There are many advantages of biodiesel if compared to diesel derived from petroleum. Biodiesel gives environmental benefits since plants, vegetable oils, and animal fats are renewable biomass sources, even it is a waste of them. There is a bundle of unique characters of biodiesel,

* Corresponding Author.

E-mail: fazlena@uitm.edu.my (F. Hamzah);

Telp: +6 0355436264 such as: no emission of greenhouse gas, nonsulfur emission, non-particulate matter pollutants, low toxicity, and biodegradable [3]. Moreover, biodiesel has the same properties as diesel fuel derived from petroleum where it can be mixed in any proportion with the diesel fuel from petroleum and the engine not necessary to have any modification to use it [4]. Moreover, the deficiency of petroleum becomes a hindrance in diesel production; even more, its disadvantage is causing global warming due to high emission of carbon dioxide, referring to diesel depletion [5].

Transesterification reaction with the catalyst can be performed either with the chemical or 
enzyme. There are two types of chemical catalyst, which is acid and base catalyst. In a base catalytic transesterification, homogenous base catalyst, such as: sodium hydroxide $(\mathrm{NaOH})$ solution and potassium hydroxide $(\mathrm{KOH})$ solution, give benefits on high conversion rate, modest operation, and abundantly available $[6,7]$. However, the difficult on recycling of homogenous catalyst after the reaction process and a large amount of alkaline wastewater produced has categorized this method as environmentally unfriendly [8]. On the other hand, transesterification with acid catalysts create problem on environment since it is generating an acidic waste stream from catalyst washing [9], which will affect the ecology of the water system. An acid catalyst like sulphuric acid $\left(\mathrm{H}_{2} \mathrm{SO}_{4}\right)$ is also highly corrosive to the equipment and hard to obtain [6]. Transesterification with heterogeneous acid catalyst help in the elimination of wastewater generation during the process by simplifying the downstream process. However, this route requires a hightemperature reaction, which results in the evaporation of acyl acceptor [10]. The high reaction temperature is needed because the solid acid catalysts have a low catalytic activity, which requires the heat to excite the action of the enzyme in longer reaction time [11].

Due to this limitation, therefore, the enzymatic reaction has been introduced in the transesterification process. One of the enzymes involved in enzymatic transesterification is lipase. The advantage of the enzyme is the ability to be reused as it is immobilized, which served in better separation of by-product and catalyst in the transesterification process [12]. The immobilized lipase can be conducted in mild condition [13], produce a high product purity [14], and able to operate a feedstock with high free fatty acid (FFA) content, such as: waste cooking oil [3]. The waste cooking oil (WCO) has been used as a feedstock in biodiesel production to reduce the environmental impact due to the relatively large quantities used in domestic and industries. The constituents in WCO can cause damages to the environment due to the formation of oily films on aquatic surfaces, which disrupts oxygen diffusion and clogging mainly caused by the emulsification with organic matter, and for oil methanization, which worsens the greenhouse effect [15]. Thus, lipase mediated biodiesel production from WCO enables a biotechnology transformation over conventional chemical processes.
Lipase works by hydrolysis, alcoholysis, esterification, and transesterification simultaneously [14]. Lipase that commonly used in industrial transesterification of biodiesel production is Candida antarctica from B, Rhizomucor miehei, Thermomyces lanuginose, Burkholderia cepacia, Candida sp. 99-125 [16]. Different lipase results in a different yield of biodiesel depend on the enzyme activity and stability towards the substrate, immobilization type, and operating condition. As reported by Gupta et al. [17], the yield of biodiesel production varied from 50 to $100 \%$ using different types of lipase.

Therefore, it is essential to determine the activity and stability of the selected enzyme before it is utilized in the reaction. Up until today, limited information was reported on the thermodynamic behavior and activity of lipase Immobilized from Pseudomonas cepacia (PcL), Thermomyces lanuginosus (TLIM), and Candida Antarctica A (CALA) in transesterification of WCO. Thus, this present study was conducted with the aim to determine the feasibility of lipase for transesterification process of WCO and its catalytic activity is also evaluated in terms of two mathematical constants, known as turn-over number $\left(k_{c a t}\right)$ and thermal deactivation constant $\left(K_{d}\right)$. The transesterification process was conducted using PcL, TLIM, and CALA. The optimum operation parameter using this lipase was investigated by varying in $\mathrm{pH}$ condition, reaction temperature, and enzyme loading. The outcomes from this study will provide sufficient information for the further exploring thermodynamic behavior of lipase catalyzed transesterification of biodiesel using WCO.

\section{Materials and Method}

\subsection{Material}

Lipase Immobilized on immobead 150 from Pseudomonas cepacia, PcL (U $\geq 900 \mathrm{U} / \mathrm{g})$, Lipase immobilized on immobead 150 from Thermomyces lanuginosus, TLIM ( $\mathrm{U} \geq 3000 \mathrm{U} / \mathrm{g}$ ) and Lipase A Candida antarctica immobilized on immobead 150, recombinant from Aspergillus oryzae, CALA $(\mathrm{U} \geq 500 \mathrm{U} / \mathrm{g})$ were purchased from Sigma Aldrich. Potassium phosphate buffer powder was purchased from EMSURE $\mathbb{}$ (Germany). The phosphoric acid (95\% purity) and potassium hydroxide (100\% purity) were purchased from R\&M Marketing (United Kingdom). p-Nitrophenyl (p-NP) powder and pnitrophenyl acetate (p-NPA) were also purchased from Sigma Aldrich. 


\subsection{Method}

The enzyme stability toward $\mathrm{pH}$ was prepared according to Babaki et al. and Willerding et al. $[18,19]$, where $5 \mathrm{mg}$ of each enzyme was incubated in $4 \mathrm{~mL}$ of $25 \mathrm{mM}$ phosphate buffer in $40{ }^{\circ} \mathrm{C}$ for 5 minutes. The $\mathrm{pH}$ of phosphate buffer was varied from 6 to 10 . Then, $1 \mathrm{~mL}$ of p-NPA solution was added to the incubated solution with enzyme, and samples were withdrawn every 5 minutes in 30 minutes. The graph of $\mathrm{p}$-NP concentration versus time was plotted, and the rate of p-NP production was calculated and compared. For the effect of temperature toward enzyme stability, the procedure and preparation were repeated as $\mathrm{pH}$ stability procedure. The enzymes were incubated at optimum $\mathrm{pH}$ solutions with varied temperatures. Then graph of $\mathrm{p}$-NP production versus time was plotted. The enzyme activity was calculated from the slope of the straight line of the absorbance versus amount of immobilized enzyme [20]. One unit of enzyme activity was defined as the amount of biocatalyst that released $1 \mu \mathrm{mol}$ of $\mathrm{p}$-NP per minute.

The kinetic study was determined at different p-NP concentration. The result then calculated by using Michaelis-Menten kinetic Equation (1) [21]. The stability of enzyme was studied at varied incubation periods. The remaining activity later determined.

$$
v=\frac{d[P]}{d t}=k_{2} \frac{\left[E_{o}\right][S]}{k_{s}+[S]}=\frac{v_{\max }[S]}{k_{s}+[S]}
$$

where, [P] denotes accumulation of product, $k_{2}$ is rate constant product formation, $k_{s}$ is dissociation constant of ES formation at half of $v_{\max }$, $\left[\mathrm{E}_{\mathrm{O}}\right]$ stands for initial concentration of enzyme, [S] denotes the concentration of substrate, and $V_{\max }$ presents the maximum rate of enzyme activity.

\section{Result and Discussion}

In enzymatic hydrolysis using lipase, lipase activity plays an essential role in the catalytic profile. The study on lipase activity was con-

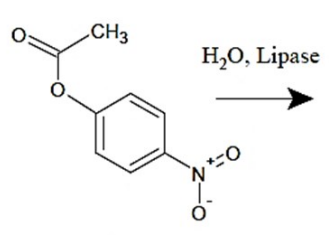

p-Nitrophenyl Acetate

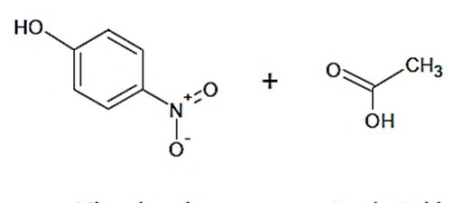

p-Nitrophenol
Figure 1. Chemical reaction mechanism of hydrolysis of $p$-NPA to $p$-NP ducted using the hydrolysis process of p-Nitrophenyl acetate (p-NPA) and producing p-Nitrophenol ( $p-N P)$ as shown in the schematic reaction in Figure 1. The activity of enzyme is influenced by the changes in its surrounding condition especially the temperature and $\mathrm{pH}$. This is because enzyme is constructed from amino acid residue that poses basic, neutral or acidic group. Therefore, this study was focused on evaluating optimum enzymatic activity at various $\mathrm{pH}$, temperature, and enzyme loading.

\subsection{Effect of Lipase Activity Towards pH}

The effect of $\mathrm{pH}$ towards enzyme was conducted at $\mathrm{pH}$ 6-10. The result is illustrated in Figure 2. In general, the active catalytic site of the enzyme only exists in one particular ionization state, which may be a more substantial or small fraction of the total enzyme present [22]. By implement the hydrolysis of p-NPA, the rate of $p$-NP production can be calculated as lipase activity. The result in Figure 2 indicates that $\mathrm{pH}$ of the solution plays an essential role in the production of $\mathrm{p}-\mathrm{NP}$. From the result, enzyme activity of PcL and CALA was optimum at $\mathrm{pH} 9$, while TLIM was at $\mathrm{pH} 8$. The result shows that the enzyme activity from the production rate of $\mathrm{p}-\mathrm{NP}$ increased from $\mathrm{pH} 6$ to $\mathrm{pH}$ 9 until it slightly reduced at $\mathrm{pH} 10$ by using CALA. A similar trend was also observed for PcL. On the other hand, for TLIM the activity increased from $\mathrm{pH} 6$ to $\mathrm{pH} 8$ but drastically reduced at $\mathrm{pH} 9$ to 10 . This finding indicated that CALA was the most stable lipase when variation of $\mathrm{pH}$ occurred in the medium. This lipase had shown its optimum activity at $\mathrm{pH}$ range of 8-9. There are two effects that responsible for this behavior of enzyme, which is the state of protonation of functional groups of amino acid

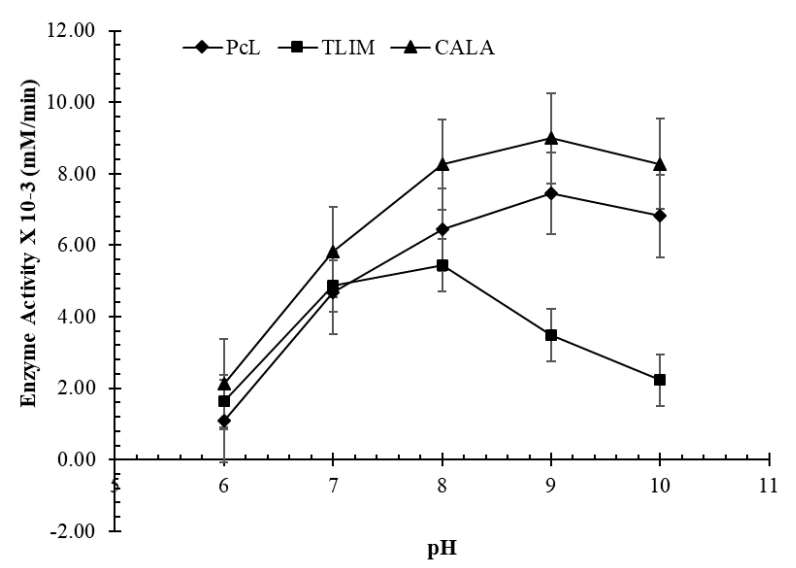

Figure 2. The production rate of p-NP in various $\mathrm{pH}$ of each type of lipase. 
and cofactors that involves in the catalytic reaction and the three-dimensional protein structure of the enzyme [23]. The protonation of functional groups of amino acids is present in the active site of each enzyme. Most of the lipase has conserved a similarity of $\alpha / \beta$-hydrolase fold consists of an eightstranded, mostly parallel $\beta$ sheet flanked by six $\alpha$ helices, with a catalytic triad which is serine, histidine and aspartic acid. Hydrolysis process in lipase mostly happened involving serine and histidine where serine holds the substrate and histidine will cleave the desired bond in the substrate for catalyzing mechanism.

Serine is an amino acid that classified under a polar and uncharged group while histidine is under acidic group. In histidine, the side chain is also contributing to the titrable group, where it is charged differently according to the $\mathrm{pH}$ condition [24]. At very low $\mathrm{pH}$ values, the histidine molecule has +2 net charges because the side chain and amino group have positive charge. At around $\mathrm{pH} 5$ the histidine appears with +1 net charges. This is occurred due to the losses of hydrogen ion in carboxyl group. As the base is added, the imidazole groups in histidine losses its proton which result no net charge present. When the hydroxide ion $(\mathrm{OH})$ is added continuously to the histidine, its amino group will lose the proton (positive charge), and now histidine molecule has a negative charge.

This situation is happened due to the unique chemical characteristic of enzyme active site which can lead the promotion, inhibition of ionization of the group located [25]. It was also stated that the hydrolysis is aided by base interaction with water bridge to carbonyl oxygen [26]. The reaction pathway is illustrated in Figure 3 showed that the carbonyl oxygen is forming polar bond with one of hydrogen in water molecule. Meanwhile, the oxygen ion from carbonyl of histidine is forming a hydrogen bond with another hydrogen in the same water molecule, since hydrogen bond is stronger than polar bond, the hydrogen atom attaches on histidine. On the other hand, serine holds the hydroxide ion from the cleaved water molecule. However, since the reaction in a base condition, the histidine proceeds on donating the hydrogen atom from the carbonyl hydroxide. Therefore, there will be hydroxide and hydrogen ion that exists in this reaction. Those ions

\section{Serine}

Histidine<smiles></smiles><smiles></smiles>

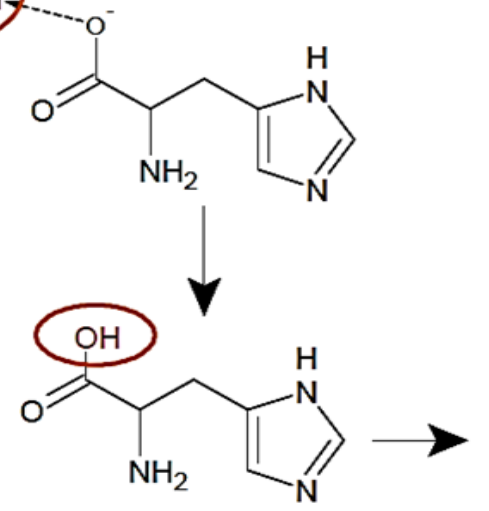<smiles>NC(Cc1cnc[nH]1)C(=O)[O-]</smiles>

Figure 3. Reaction pathway of lipase catalytic function for hydrolysis.

Table 1. Comparison of the $\mathrm{pH}$ condition for lipase.

\begin{tabular}{lcc}
\hline \multicolumn{1}{c}{ Type of Lipase } & $\mathrm{pH}$ optimum & Reference \\
\hline PcL & 9 & {$[40]$} \\
Candida antarctica Lipase B (CALB) & $7-8$ & {$[41]$} \\
Candida rugosa on chitosan & $8-9$ & {$[42]$} \\
Candida rugosa on chitosan with activated $\mathrm{OH}_{\text {group }}$ & 8.5 & {$[43]$} \\
Candida rugosa immobilised on chitosan-coated $\mathrm{Fe}_{3} \mathrm{O}_{4}$ nanoparticle & 7 & {$[44]$} \\
\hline
\end{tabular}


are accepted by p-NPA, primary substrate, in the determination of lipase activity.

The hydronium ion is oxidized by using hydroxide ion that holds by serine. This happened due to unstable chemical position on serine as a result of addition hydroxide ion-molecule and the hydrogen bond that forms through the oxidation process. Then, the acetic acid accepts the hydrogen atom that is released by histidine. Therefore, the increase of $\mathrm{pH}$ is considerably influencing the enzyme activity to reach its velocity at maximum value. This is because lipase needed base environment to enhance the hydrolysis process. Below and above the optimum $\mathrm{pH}$, the activity of enzyme is much lower, and at the extreme $\mathrm{pH}$, the enzyme is inactive [27]. Similar findings on the lipase-catalyzed hydrolysis process also indicated that the activity of lipase from Candida and Pseudomonas $s p$ were optimized at alkaline conditions as the data listed in Table 1.

\subsection{Effect of Lipase Activity Towards Tempera-} ture

The study of lipase behavior toward the temperature variation at $\mathrm{pH} 9$ for $\mathrm{PcL}$ and $\mathrm{CA}$ LA, and $\mathrm{pH} 8$ for TLIM were recorded in Figure 4. From the study, the rate of $\mathrm{p}-\mathrm{NP}$ production by a lipase from PcL was increased as the temperature rise from $30{ }^{\circ} \mathrm{C}$ to $40^{\circ} \mathrm{C}$ and showed slightly decrease in the rate when the temperature rises to $50{ }^{\circ} \mathrm{C}$. A similar performance was also obtained for TLIM and CALA. However, for PcL, the activity was almost constant at temperature range of $40-45{ }^{\circ} \mathrm{C}$ before a slight decrement of activity was detected between temperatures $45-50{ }^{\circ} \mathrm{C}$.

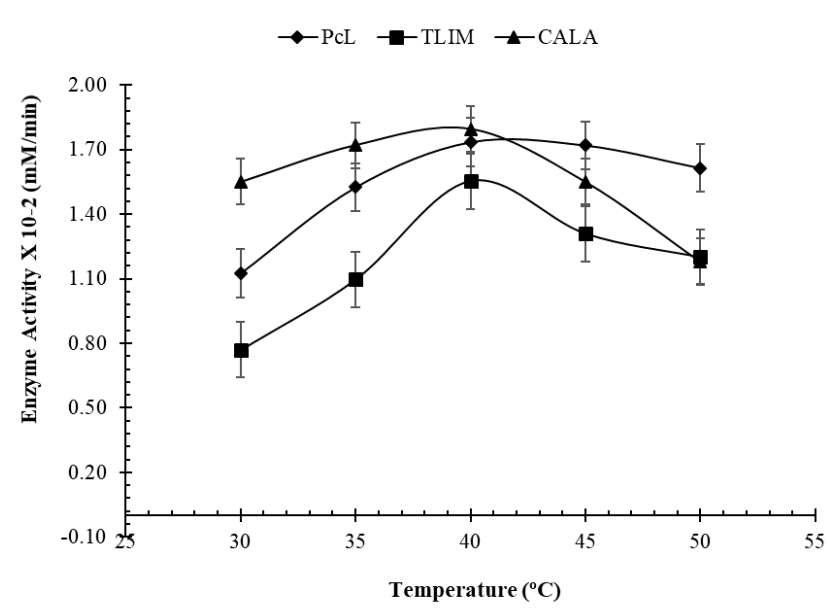

Figure 4. The production rate of $\mathrm{p}-\mathrm{NP}$ in various temperature.
Generally, enzymatic reaction is temperature-dependent where the rate of reaction increased as the temperature was elevated. However, at a higher temperature, denaturation occurs to the enzyme. This is because the conformation of enzyme molecules is made up of polymer consist of amino acid that linked together by covalent peptide bond. However, in the formation of tertiary and quaternary structure of enzyme, the peptide bond is supported by $\alpha$ helix and $\beta$-pleated sheet that stabilized by hydrogen bond [24]. Besides, the interaction between enzyme and substrates is usually van der Waals force and hydrogen bonding. This reaction is the weakest forces that happened between any atoms [28]. Thus, the bonds are easily broken when additional heat energy from surrounding is obtained by the enzyme. This heat energy turns to kinetic energy driving the reaction faster, but over the limit damages the bonding involved in conformation of enzyme and result in the inhibition. Thus, from this finding the result suggested that the optimum temperature for PcL, TLIM, and CALA was 40 ${ }^{\circ} \mathrm{C}$. A similar outcome has been reported by Caetano et al., Raita et al., and Subhedar \& Gogate [29-31] who indicated that the optimum temperature for TLIM was 40,50 , and $35^{\circ} \mathrm{C}$, respectively. With respect to CALB, the optimum temperature as reported by Ognjanovic et al. and Amini et al. [32,33] was $45^{\circ} \mathrm{C}$, while 50 ${ }^{\circ} \mathrm{C}$ was reported by Babaki et al. [19]. On the other hand, Lopresto et al. [34] reported that the optimum temperature for PcL was $37^{\circ} \mathrm{C}$. The variation of the optimum temperature was varied from $3{ }^{\circ} \mathrm{C}$ to $10{ }^{\circ} \mathrm{C}$ depend on the lipase and substrate that has been used in the process.

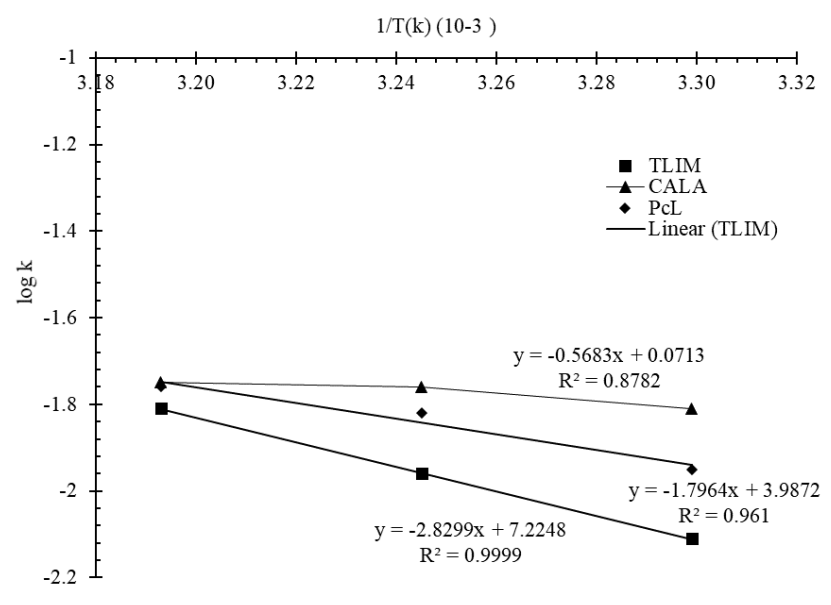

Figure 5. The Arrhenius plots for lipase. 
The rate of hydrolytic activity increased as the temperature increased, but it started to slow down as the temperature keep increasing over the thermal stability of the enzyme. The increase in hydrolytic activity is aid by an energy known as activation energy. Activation energy is defined as the height of a barrier the reactant and product [35]. The function of enzyme is to lower down the activation energy of reaction by binding the substrate and forming the ES complex. The Gibb's free energy does not affect by the enzymatic reaction. The activation energy for uncatalyzed reaction is $18 \mathrm{kcal} / \mathrm{mol}$, while enzymatic catalyzed must be $7 \mathrm{kcal} / \mathrm{mol}$ and below. The related chemical behavior that dependence on temperature is always obeying to Arrhenius Law where the effect of activation energy and temperature on the rate constant is given by Arrhenius equation [21]. The Arrhenius plot of the experiment data is illustrated in Figure 5.

The result shows that the activation energy of lipase from PcL, TLIM, and CALA are 4.66 $\mathrm{kJ} / \mathrm{mol} \quad(1.11 \mathrm{kcal} / \mathrm{mol}), \quad 7.53 \mathrm{~kJ} / \mathrm{mol} \quad(1.77$ $\mathrm{kcal} / \mathrm{mol})$ and $1.58 \mathrm{~kJ} / \mathrm{mol}(0.378 \mathrm{kcal} / \mathrm{mol}) \mathrm{re}$ spectively. The activation energy was taken at $40{ }^{\circ} \mathrm{C}$ which is the optimum temperature for each type of the lipase. From the study, the highest activation energy was recorded by TLIM, while the lowest activation energy was observed from the reaction catalyzed by CALA. This result suggested that the slowest reaction rate can be obtained by TLIM and the highest reaction rate is by CALA. According to data, CALA needed only small amount of activation energy in achieving the equilibrium phase in hydrolytic activity to form enzyme-substrate complex [36]. Thus, the lower the energy required will reflect on the faster of the reaction which reveals a better enzyme activity. The other study has recorded different values of activation energy. The study by Ferreira et al. [36], indicated that lipase from Geotrichum candidum required $34.50 \mathrm{~kJ} / \mathrm{mol}$ of activation energy. While lipase from Aspergillus awamori as studied by Mostafa et al. [37], required $32.75 \mathrm{~kJ} / \mathrm{mol}$ activation energy, and 10.54 $\mathrm{kJ} / \mathrm{mol}$ activation energy was needed by lipase from Candida rugosa as claimed by Onoja et al. [38]. From the data, the activation energy was different according to the other kind of lipase. However, Candida species have shown the lowest activation energy. Therefore, the CALA would be the best enzyme for transesterification process due to its low activation energy.

\subsection{Effect of Enzyme Loading Towards Enzyme Activity}

The activity of lipase was evaluated by varying the amount of immobilized enzyme loading under the optimum $\mathrm{pH}$ and temperature. The result of lipase activity is plotted in Figure 6. Enzyme activity is representing maximum catalytic power of the enzyme in the environmental condition used. Figure 6 indicates that the activity of lipase was increased as the amount of enzyme was increased. This can be relating to the present of the higher available active site with higher loading of enzyme that encourages for more reaction to occurs. The activity of lipase is represented as the rate of $p$ NP production in a unit of $\mathrm{mM}$ from $\mathrm{p}$-NPA solution in a minute. The rate of $\mathrm{p}-\mathrm{NP}$ production for lipase from PcL and CALA further increased as the amount of enzyme were increased from $10 \mathrm{mg}$ to $20 \mathrm{mg}$, but the activity started to decrease at $25 \mathrm{mg}$ of enzyme loading.

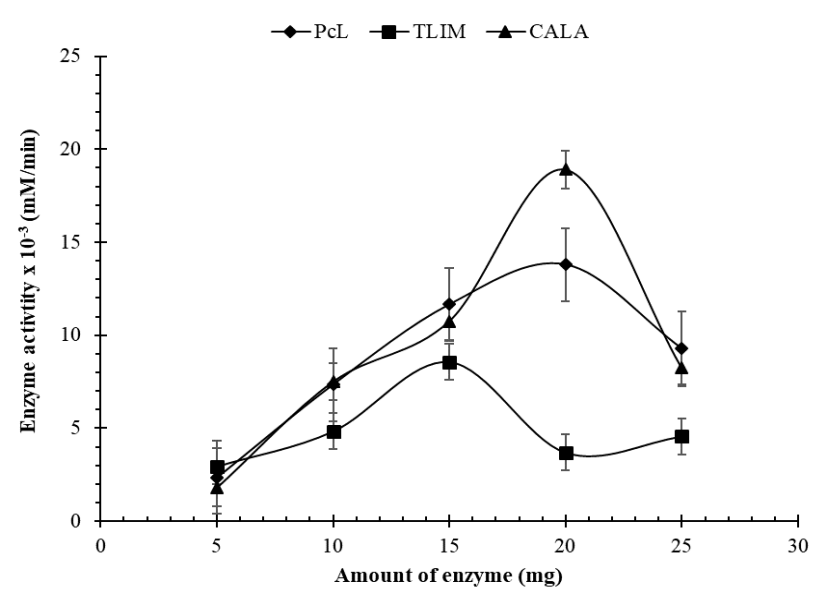

Figure 6. The activity of each lipase at different amount of enzyme.

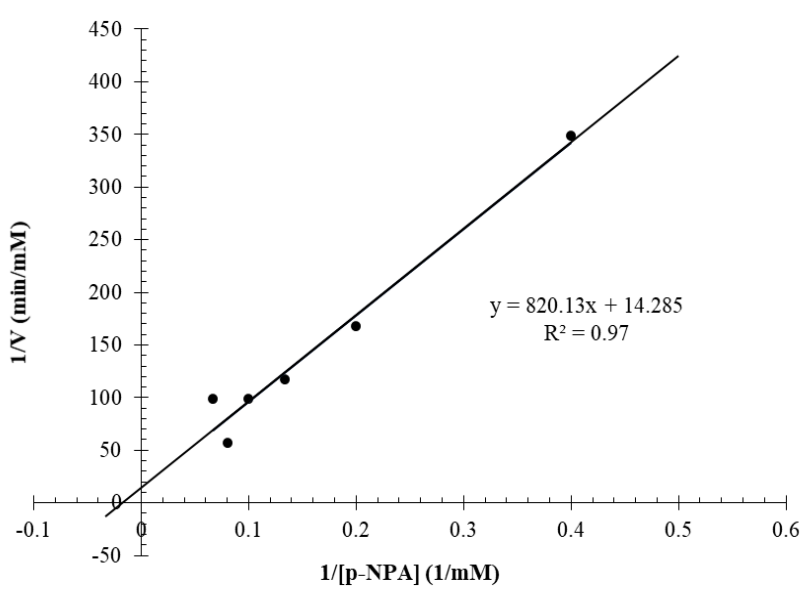

Figure 7. Kinetic of CALA in the hydrolysis of p-NPA. 
Meanwhile for TLIM, the maximum reaction rate is at $15 \mathrm{mg}$ of enzyme and the decreasing in enzyme activity was detected from $15 \mathrm{mg}$ onwards.

This happened due to the hindrance on active site to bind with the substrate as claimed by Bhangu et al. [39]. At a high concentration of enzyme, it will tend to agglomerate to each other. Also, according to Marangoni [25], the drop on the enzyme activity at high loading of enzyme is because the substrate is depleted

Table 2. The kinetics parameter hydrolysis of p-NPA using CALA.

\begin{tabular}{lc}
\hline \multicolumn{1}{c}{ Kinetic parameter } & $\begin{array}{c}\text { Kinetics } \\
\text { value }\end{array}$ \\
\hline$V_{\max }(\mu \mathrm{M} / \mathrm{min})$ & 70 \\
$K_{m}(\mathrm{mM})$ & 57.412 \\
$k_{\text {cat }}\left(\mathrm{min}^{-1}\right)$ & 1.615 \\
$k_{1}(\mathrm{mM} / \mathrm{min})$ & $4.88 \times 10^{-4}$ \\
$k_{-1}(\mathrm{mM} / \mathrm{min})$ & 0.028 \\
Catalytic efficiency $\left(\min ^{-1} \cdot \mathrm{M}^{-1}\right)$ & 28.13 \\
\hline
\end{tabular}

which affects the saturation degrees of enzyme. Therefore, the highest activity was recorded at $20 \mathrm{mg}$ of CALA which gave $1.89 \times 10^{-3} \mathrm{mM} / \mathrm{min}$, while the activity of PcL and TLIM were $1.38 \times 10^{-3} \mathrm{mM} / \mathrm{min}$ and $0.86 \times 10^{-3} \mathrm{mM} / \mathrm{min}$, respectively. Since CALA had shown the highest activity, thus, CALA was selected in the next kinetic study of lipase and transesterification process.

\subsection{Kinetics of Enzyme}

The kinetics study of CALA was conducted by varying the concentration of p-NPA as a substrate in the production of $\mathrm{p}-\mathrm{NP}$ by the hydrolysis process, and the results were illustrated in Figure 7. It is applicable for CALA to be kinetically controlled because the reaction velocity or activity was directly proportional to the enzyme concentration as stated by Marangoni [25]. In this mechanism, the inhibition of substrate towards the enzyme does not consider. The behavior of the enzyme is predicted using experimental data and mathematically represented by referring the concept in MichaelisMenten's kinetic. The qualitative feature of set

Table 3. Comparison between $K_{m}$ and $V_{m}$ for lipase catalysis of the reaction.

\begin{tabular}{|c|c|c|c|c|}
\hline \multirow{2}{*}{ Enzyme } & \multirow{2}{*}{ Substrate } & \multicolumn{2}{|c|}{ Kinetic Parameter } & \multirow{2}{*}{ Refs. } \\
\hline & & $V_{\max }$ & $K_{\mathrm{m}}$ & \\
\hline CALA & $\begin{array}{l}\text { p-Nitrophenyl ace- } \\
\text { tate (p-NPA) }\end{array}$ & $70 \mu \mathrm{M} / \mathrm{min}$ & $57.412 \mathrm{mM}$ & $\begin{array}{l}\text { Current } \\
\text { study }\end{array}$ \\
\hline Novozym 435 & Waste cooking oil & $18 \mathrm{mM} / \mathrm{min}$ & $1030 \mathrm{M}$ & {$[45]$} \\
\hline Novozym 435 & $\begin{array}{l}\text { Isoamyl alcohol and } \\
\text { acetic anhydride }\end{array}$ & $\begin{array}{l}52.08 \\
\mathrm{mmol} / \mathrm{g} \cdot \mathrm{min}\end{array}$ & $\begin{array}{c}0.26 \mathrm{mM} \text { (Acetic anhy- } \\
\text { dride) } 0.96 \mathrm{mM} \\
\text { (Isoamyl alcohol) }\end{array}$ & [41] \\
\hline $\begin{array}{l}\text { Candida rugosa im- } \\
\text { mobilized on chitosan }\end{array}$ & Olive oil & $51 \mathrm{mmol} / \mathrm{g} \cdot \min$ & $0.15 \mathrm{mM}$ & {$[46]$} \\
\hline Mucor meihei & Tributyrin & $3.0 \mathrm{mmol} / \mathrm{m}^{3} . \mathrm{s}$ & $160.40 \mathrm{mM}$ & {$[47]$} \\
\hline Aspergillus awamori & Glucose & $77 \mathrm{mM} / \mathrm{min}$ & $230 \mathrm{M}$ & {$[37]$} \\
\hline $\begin{array}{l}\text { Geotrichum can- } \\
\text { didum immobilised } \\
\text { in agarose }\end{array}$ & $\begin{array}{c}\text { Methyl phe- } \\
\text { nylacetate } \\
\text { Methyl mandelate }\end{array}$ & $46.30 \mathrm{IU} / \mathrm{mL}$ & $261.77 \mathrm{mM}$ & {$[36]$} \\
\hline $\begin{array}{l}\text { Rhizomocur meihei } \\
\text { immobilized on mi- } \\
\text { croporous anion ex- } \\
\text { change resin }\end{array}$ & Jatropha oil & $39 \mathrm{mM} / \mathrm{h} . \mathrm{g}$ & $\begin{array}{c}K_{\mathrm{m}(\mathrm{COOH})}=203 \mathrm{mM} \\
K_{\mathrm{m}(\mathrm{OH})}=31 \mathrm{mM}\end{array}$ & [48] \\
\hline Novozym 435 & $\begin{array}{l}\text { Geraniol and Vinyl } \\
\text { acetate }\end{array}$ & $43.48 \mathrm{mM} / \mathrm{min}$ & $2134 \mathrm{mM}$ & {$[49]$} \\
\hline $\begin{array}{l}\text { Bulkholderia cepacia } \\
\text { immobilized on cho- } \\
\text { linium based eutectic }\end{array}$ & $\begin{array}{l}\text { p-Nitrophenyl pal- } \\
\text { mitate }\end{array}$ & $0.017 \mu \mathrm{M} / \mathrm{min}$ & $1.5 \mu \mathrm{M}$ & [50] \\
\hline
\end{tabular}


data of experiments must comply certain requirements which the reaction is first-order reaction, the substrate concentration is continually increased, and the reaction rate is proportional to the amount of enzyme [21]. The kinetic parameter according to Figure 7 was tabulated in Table 2 with the coefficient of determination $\left(\mathrm{R}^{2}\right)$ of the reaction was 0.97 . According to the result, $K_{m}$ and $V_{\max }$ for hydrolysis of p-NPA with CALA in this study were $57.41 \mathrm{mM}$ and $70 \mu \mathrm{M} / \mathrm{min}$, respectively. The results indicated that $K_{m}$ and $V_{m}$ values were at part with other studies on lipase kinetics as tabulated in Table 3. In general, lipase catalyzed hydrolysis reaction will result in an average $V_{m}$ value of $0.017-77 \mathrm{mM} / \mathrm{min}$ and for $K_{m}$, the average value will be $1.5 \mu \mathrm{M}$ to $1030 \mathrm{M}$ which will depend on the substrate and enzyme that has been used. The enzymatic reaction mechanism usually involves a two-step reaction, which is the enzyme-substrate and product formations. The enzyme-substrate formation reaction is reversible, while the product formation is usually irreversible; the reaction is elaborated in Equation (3).

$$
\begin{aligned}
& v=-\frac{d S}{d t}=\frac{d P}{d t} \\
& E+S \stackrel{k_{1}}{\underset{k_{-1}}{\rightleftharpoons}} E S \stackrel{k_{2}}{\longrightarrow} E+P
\end{aligned}
$$

where, $E$ denotes concentration of enzyme, $S$ is concentration of substrate, $E S$ stands for concentration of Enzyme-Substrate molecule, $P$ is product formation, $k_{1}$ is rate constant of substrate formation, $k_{-1}$ is rate constant of product dissociation, and $k_{2}$ is rate constant product formation.

Ideally, it is desired to achieve low $K_{m}$ and higher $V_{\max }$. The value of $V_{\max }$ represents the ability of the enzyme in utilizing the substrate to form product, while $K_{m}$ is the affinity of substrate towards the enzyme active site. A higher value of $V_{\max }$ gives the maximum esterification rate of an enzyme [38], while a lower value of $K_{m}$ of an enzyme shows high affinity of the enzyme-substrate complex [37]. Higher $K_{m}$ value indicated that the enzyme does not bind as efficiently with the substrate and $V_{\max }$ was only reached if the substrate concentration is high enough to saturate the enzyme. From the result, the calculated catalytic efficiency of CALA was $28.13 \mathrm{~min}^{-1} . \mathrm{M}^{-1}$. This rate constant determines either rate is limited by the reaction of product or the amount of substrate in the environment. However, in this study, the substrate- binding step is assumed to be fast related to the rate of ES complex breakdown. The dissociation constant for ES complex is denoted as $K_{d}$.

In most cases of steady-state reaction, the substrate-binding occurs faster than the breakdown of the ES complex. Thus, $K_{m}$ is equal to $K_{d}$ and $K_{2}$ is neglected. With higher value of rate of efficiency obtained in the study, the results suggest that enzyme complex converts a greater proportion of substrate it binds into the product which is $\mathrm{p}-\mathrm{NP}$.

\section{Conclusion}

Screening on the activity and stability of three immobilized lipases from Pseudomonas cepacia, PcL, Thermomyces lanuginosus, TLIM, and Lipase Candida Antarctica A (recombinant from Aspergillus oryzae), CALA, have been conducted on various $\mathrm{pH}$, temperature and enzyme loading. The results shown that the optimum $\mathrm{pH}$ for all lipases was at basic condition. The thermal profile revealed that all immobilized lipases have mild temperatures for their optimum condition with CALA required the lowest activation energy for the reaction compare to other lipases. The amount of the enzyme loading (CALA) needed to reach the maximum enzymatic activity was $20 \mathrm{mg}$, which gave the activity up to $1.89 \times 10^{-3} \mathrm{mM} / \mathrm{min}$. The kinetics study indicated that the kinetic parameter, $K_{m}$ is higher than the $V_{\max }$ value. The obtained kinetic parameter values indicated a high affinity of the enzyme towards the substrate is necessary in order to achieve higher production. These findings provided an understanding of the biocatalytic activity for further used in prediction of the other reaction condition and yield, and the results imply that CALA is a beneficial biocatalyst to apply to the different reaction, such as transesterification reaction.

\section{Acknowledgments}

The author is gratefully acknowledged to Universiti Teknologi MARA (UiTM) for financially and technically supporting this research under Dana/KCM 5/3/Lestari (132/2017), 600IRMI 5/3/GIP (002/2019) and 600-IRMI/DANA 5/3/REI (0009/2016) and highly appreciation to Malaysia Ministry of Higher Education for the continuous support in the academic research. 


\section{References}

[1] Borba, B.S.M.C., Lucena, A.F.P., Cunha, B.S.L., Szklo, A., Schaeffer, R. (2017). Diesel imports dependence in Brazil: A demand decomposition analysis. Energy Strateg. Rev., 18, 63-72.

[2] Patil, P.D., Gude, V.G., Reddy, H.K., Muppaneni, T., Deng, S. (2012). Biodiesel Production from Waste Cooking Oil Using Sulfuric Acid and Microwave Irradiation Processes. J. Environ. Prot. (Irvine,. Calif)., 03(01), 107113.

[3] Raqeeb, M.A.R.B. (2015). Biodiesel Production from Waste Cooking Oil. J. Chem. Pharm. Reseacrh., 7 (12), 670-681.

[4] Santin, C.M.T., Michelin, S., Scherer, R.P., Valério, A., Luccio, M.D., Oliveira, D., Oliveira, J.V. (2017). Comparison of macauba and soybean oils as substrates for the enzymatic biodiesel production in ultrasoundassisted system. Ultrason. Sonochem., 35, $525-528$.

[5] Nel, W.P., Cooper, C.J. (2009). Implications of fossil fuel constraints on economic growth and global warming. Energy Policy, 37(1), 166180 .

[6] Abdullah, S.H.Y.S., Hanapi, N.H.M., Azid, A., Umar, R., Juahir, H., Khatoon, H., Endut, A. (2016). A review of biomass-derived heterogeneous catalyst for a sustainable biodiesel production. Renew. Sustain. Energy Rev., 70, 1040-1051.

[7] Kusdiana, D., Saka, S. (2004). Effects of water on biodiesel fuel production by supercritical methanol treatment. Bioresour. Technol., 91(3), 289-295.

[8] Xie, W., Fan, M. (2014). Biodiesel production by transesterification using tetraalkylammonium hydroxides immobilized onto SBA-15 as a solid catalyst. Chem. Eng. J., 239, 60-67.

[9] Farooq, M., Ramli, A. (2015). Biodiesel production from low FFA waste cooking oil using heterogeneous catalyst derived from chicken bones. Renew. Energy, 76, 362-368.

[10] Mardhiah, H.H., Ong, H.C., Masjuki, H.H., Lim, S., Lee, H.V. (2017). A review on latest developments and future prospects of heterogeneous catalyst in biodiesel production from non-edible oils. Renew. Sustain. Energy Rev., 67, 1225-1236.

[11] Pourzolfaghar, H., Abnisa, F., Daud, W.M.A.W., Aroua, M.K. (2016). A review of the enzymatic hydroesterification process for biodiesel production. Renew. Sustain. Energy Rev., 61, 245-257.

[12] Duarte, S.H., del Peso Hernández, G.L., Canet, A., Benaiges, M.D., Maugeri, F., Vale- ro, F. (2015). Enzymatic biodiesel synthesis from yeast oil using immobilized recombinant Rhizopus oryzae lipase. Bioresour. Technol., 183, 175-180.

[13] Surendhiran, D., Vijay, M. (2013). Interesterification of Marine Microalga Chlorella salina Oil with Immobilized Lipase as Biocatalyst Using Methyl Acetate as an Acyl Acceptor. Int. J. Environ. Bioenergy., 8(2), 68-85.

[14] Yu, C.Y., Huang, L.Y., Kuan, I.C., Lee, S.L. (2013). Optimized production of biodiesel from waste cooking oil by lipase immobilized on magnetic nanoparticles. Int. J. Mol. Sci., 14(12), 24074-24086.

[15] Kumar, G., Kumar, D., Poonam, P., Johari, R., Singh, C.P. (2011). Enzymatic transesterification of Jatropha curcas oil assisted by ultrasonication. Ultrason. Sonochem., 18(5), 923-927.

[16] Zhao, X., Qi, F., Yuan, C., Du, W., Liu, D. (2015). Lipase-catalyzed process for biodiesel production: Enzyme immobilization, process simulation and optimization. Renew. Sustain. Energy Rev., 44, 182-197.

[17] Gupta, S., Bhattacharya, A., Murthy, C.N. (2013). Tune to immobilize lipases on polymer membranes: Techniques, factors and prospects. Biocatal. Agric. Biotechnol., 2(3), 171190.

[18] Willerding, A.L., Da Rocha Carvalho Neto, F.G.M., Da Gama, A.M., Carioca, C.R.F., De Oliveira, L.A. (2012). Hydrolytic activity of bacterial lipases in amazonian vegetable oils. Quim. Nova, 35(9), 1782-1786.

[19] Babaki, M., Yousefi, M., Habibi, Z., Mohammadi, M., Yousefi, P., Mohammadi, J., Brask, J. (2016). Enzymatic production of biodiesel using lipases immobilized on silica nanoparticles as highly reusable biocatalysts: Effect of water, t-butanol and blue silica gel contents. Renew. Energy, 91, 196-206.

[20] Pencreac'h, G., Leullier, M., Baratti, J.C. (1997). Properties of free and immobilized lipase from Pseudomonas cepacia. Biotechnol. Bioeng., 56(2), 181-189.

[21] Bailey, J.E., Ollis, D.F. (2011). Biochemical Engineering Fundamental. New York: McGRAW- HILL International.

[22] Furlan, S. A., Pant, H.K. (2006). General properties. In Enzyme Technology. Pandey, A., Webb, C., Soccol, C.R., Larroche, C. Eds. New Delhi: Springer, 11-35.

[23] Bisswanger, H. (2014). Enzyme assays. Perspect. Sci., 1(1-6), 41-55.

[24] Campbell, M.K., Farrell, S.O. (2012). Biochemistry. Internatio. Mary Finch. 
[25] Marangoni, A.G. (2003). Enzyme kinetics: a modern approach, vol. 27 ed. 2, United States of America: John Wiley \& Sons, Inc.

[26] Rauwerdink, A., Kazlauskas, R.J. (2017). How the Same Core Catalytic Machinery Catalyzes 17 Different Reactions: the SerineHistidine-Aspartate Catalytic Triad of $a / b$ Hydrolase Fold Enzymes Alissa. HHS Public Access, 5(10), 1252-1260.

[27] Inamdar, S.T.A. (2007). Biochemical Engineering: Principle and Concepts. New Delhi: Asoke K. Ghosh, Prentice-Hall of India.

[28] Shuler, M.L., Kargi, F. (2002). Bioprocess Engineering Basic Concepts, The Physic. Prentice Hall Ptr. Int.

[29] Subhedar P.B., Gogate, P. R. (2016). Ultrasound assisted intensification of biodiesel production using enzymatic interesterification. Ultrason. Sonochem., 29, 67-75.

[30] Raita, M., Arnthong, J., Champreda, V., Laosiripojana, N. (2015). Modification of magnetic nanoparticle lipase designs for biodiesel production from palm oil. Fuel Process. Technol., 134, 189-197.

[31] Caetano, N.S., Teixeira, J.I.M., Mata, T.M. (2012). Enzymatic Catalysis of Vegetable Oil with Ethanol in the Presence of Co-solvents. Chem. Eng. Technol., 26, 81-86.

[32] Ognjanovic, N., Bezbradica, D., KnezevicJugovic, Z. (2009). Enzymatic conversion of sunflower oil to biodiesel in a solvent-free system: Process optimization and the immobilized system stability. Bioresour. Technol., 100(21), 5146-5154.

[33] Amini, Z., Ong, H.C., Harrison, M.D., Kusumo, F., Mazaheri, H., Ilham, Z. (2017). Biodiesel production by lipase-catalyzed transesterification of Ocimum basilicum L. (sweet basil) seed oil. Energy Convers. Manag., 132, 82-90.

[34] Lopresto, C.G., Naccarato, S., Albo, L., Paola, M.G., Chakraborty, S., Curcio, S., Calabrò, V. (2015). Enzymatic transesterification of waste vegetable oil to produce biodiesel. Ecotoxicol. Environ. Saf., 121, 229-235.

[35] David, A.V., Peter, F.S., James, E.A. (2006). Environmental Biology for Engineerings and Scientists. New Jersey: John Wiley \& Sons, Inc.

[36] Ferreira, M.M., Santiago, F.L.B., Silva, N.A.G.D., Luiz, J.H.H., Fernandéz-Lafuente, R., Mendes, A.A., Hirata, D.B. (2018). Different strategies to immobilize lipase from Geotrichum candidum: Kinetic and thermodynamic studies. Process Biochem., 67, 55-63.
[37] Mostafa, F.A., Abdel Wahab, W.A., Salah, H.A., Nawwar, G.A.M., Esawy, M.A. (2018). Kinetic and thermodynamic characteristic of Aspergillus awamori EM66 levansucrase. Int. J. Biol. Macromol., 119, 232-239.

[38] Onoja, E., Chandren, S., Razak, F.I.A., Wahab, R.A. (2018). Enzymatic synthesis of butyl butyrate by Candida rugosa lipase supported on magnetized-nanosilica from oil palm leaves: Process optimization, kinetic and thermodynamic study. J. Taiwan Inst. Chem. Eng., 91, 105-118.

[39] Bhangu, S.K., Gupta, S., Ashokkumar, M. (2017). Ultrasonic enhancement of lipasecatalysed transesterification for biodiesel synthesis. Ultrason. Sonochem., 34, 305-309.

[40] Kademi, A., Leblanc, D., Houde, A. (2005). Lipases, in Enzyme Technology, Pandey, A., Webb, C., Soccol, C.R., Larroche, C. Eds. India: Springer, 297-318.

[41] Romero, M.D., Calvo, L., Alba, C., Daneshfar, A. (2007). A kinetic study of isoamyl acetate synthesis by immobilized lipase-catalyzed acetylation in n-hexane. J. Biotechnol., 127(2), 269-277.

[42] Hung, T.C., Giridhar, R., Chiou, S.H., Wu, W.T. (2003). Binary immobilization of Candida rugosa lipase on chitosan. J. Mol. Catal. B Enzym., 26(1-2), 69-78.

[43] Chiou, S.H., Wu, W.T. (2004). Immobilization of Candida rugosa lipase on chitosan with activation of the hydroxyl groups. Biomaterials, 25(2), 197-204.

[44] Kuo, C.H., Liu, Y.C., Chang, C.M.J., Chen, J.H., Chang, C., Shieh, C.J. (2012). Optimum conditions for lipase immobilization on chitosan-coated $\mathrm{Fe} 3 \mathrm{O} 4$ nanoparticles. Carbohydr. Polym., 87(4), 2538-2545.

[45] Azócar, L., Navia, R., Beroiz, L., Jeison, D. Ciudad, G. (2014). Enzymatic biodiesel production kinetics using co-solvent and an anhydrous medium: A strategy to improve lipase performance in a semi-continuous reactor. N. Biotechnol., 31(5), 422-429.

[46] Pereira, E., De Castro, H., De Moraes, F., Zanin, G. (2001). Kinetic studies of lipase from Candida rugosa. Appl. Biochem. Biotechnol., 91-93, 739-752.

[47] Al-Zuhair, S. (2006). Kinetics of Hydrolysis of Tributyrin By Lipase. J. Eng. Sci. Technol., 1(1), 50-58.

[48] Gofferjé, G., Stäbler, A., Herfellner, T., Schweiggert-Weisz, U., Flöter, E. (2014). Kinetics of enzymatic esterification of glycerol and free fatty acids in crude Jatropha oil by immobilized lipase from Rhizomucor miehei. J. Mol. Catal. B Enzym., 107, 1-7. 
[49] Murcia, M.D., Gómez, M., Gómez, E., Gómez, J.L., Hidalgo, A.M., Sánchez, A., Vergara, P. (2018). Kinetic modelling and kinetic parameters calculation in the lipase-catalysed synthesis of geranyl acetate. Chem. Eng. Res. Des., 138, 135-143.
[50] Juneidi, I., Hayyan, M., Hashim, M.A., Hayyan, A. (2017). Pure and aqueous deep eutectic solvents for a lipase-catalysed hydrolysis reaction. Biochem. Eng. J., 117, 129-138.

Selected and Revised Papers from International Symposium of Green Engineering and Technology 2019 (ISGET 2019)

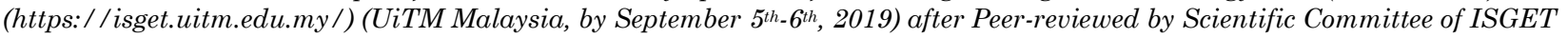
2019 and Peer-Reviewers of Bulletin of Chemical Reaction Engineering \& Catalysis. 